\title{
"Employment until the end of the world": exploring the role of manipulation in a Mozambican land deal
}

Article

Accepted Version

Creative Commons: Attribution-Noncommercial-No Derivative Works 4.0

Revised version

Arnall, A. (2019) "Employment until the end of the world": exploring the role of manipulation in a Mozambican land deal. Land Use Policy, 81. pp. 862-870. ISSN 0264-8377 doi: https://doi.org/10.1016/j.landusepol.2017.11.055 Available at https://centaur.reading.ac.uk/74136/

It is advisable to refer to the publisher's version if you intend to cite from the work. See Guidance on citing.

To link to this article DOI: http://dx.doi.org/10.1016/j.landusepol.2017.11.055

Publisher: Elsevier

All outputs in CentAUR are protected by Intellectual Property Rights law, including copyright law. Copyright and IPR is retained by the creators or other copyright holders. Terms and conditions for use of this material are defined in the End User Agreement.

www.reading.ac.uk/centaur

\section{CentAUR}


Central Archive at the University of Reading

Reading's research outputs online 


\section{"Employment until the end of the world": Exploring the role of manipulation in a Mozambican land deal}

\section{Abstract}

In recent years, there has been considerable controversy over the poverty and livelihood impacts of large-scale land acquisitions (LSLAs) on small-scale farmers in sub-Saharan Africa. However, while much of the concern over LSLAs has stemmed from the phenomenon of coercive expulsion of farmers from their lands, far less attention has been paid to the mechanism of manipulation, which is arguably a subtler and more pervasive form of influence over smallholders when they are incorporated into major land deals. This article addresses this theoretical and empirical gap through a case study of a LSLA implemented by an international paper and pulp company for the development of an extensive eucalyptus plantation in central Mozambique. The findings highlight the roles of three forms of manipulative influence - namely deception, pressure to acquiesce and playing upon people's emotions - that were evident during company-smallholder negotiations and the impacts that these had on farmers' livelihoods. The article concludes that, in the study of LSLAs, a much wider range of influences should be taken into consideration during the implementation of land deals than is currently the case. This is particularly important when external investors seek to develop new markets for land in which small-scale landholders can engage on a supposedly voluntary basis in search of jobs and income.

Keywords: Large-scale land acquisition; expulsion; manipulation; livelihoods; Mozambique.

\section{Introduction}

Since the global economic crisis of 2008, the poverty and livelihood effects of large-scale land acquisitions (LSLAs) implemented by international corporations in developing countries have become a topic of considerable interest amongst researchers, policymakers and civil society organisations. To date, much of the concern surrounding LSLAs has been based on what can be characterised as an expulsion-resistance narrative, according to which small-scale farmers are displaced from their lands, often by coercive means, with the result they engage in some kind of confrontation with, or resistance to, the activities of the external investor (Borras and Franco, 2012). However, while the expulsion of farmers from their lands does undoubtedly take place in some cases, it has also been pointed out that not all LSLAs necessarily result in eviction, and that not all 
farmers might seek to resist, or be unable to profit from, large-scale land deals (Mamonova, 2015). Instead, there might occur a process of negotiation between farmers and external investors in which smallholders seek inclusion in LSLA projects from which they aim to profit financially. In this latter case, there is need for better understanding of how small-scale farmers are incorporated into largescale agricultural development projects and what the consequences of these social processes might be for them (Wolford et al., 2013).

The aim of this article is to help address this need by demonstrating the importance of manipulative, rather than coercive, influence in understanding how LSLAs proceed and the impacts that they have on small-scale farmers. To date, manipulation has been given little systematic consideration in the study of LSLAs, a trend reflected by the wider philosophical and political literature on influence and power, in spite of its potentially pervasive existence in daily life (Coons and Weber, 2014). This article addresses this theoretical and empirical gap through presentation of a case study of a LSLA implemented by an international paper and pulp company for the development of an extensive eucalyptus plantation in central Mozambique, a project which begun 2009 and continues to this present day. Through a series of semi-structured interviews with key informants and small-scale farmers carried out in 2015 and 2016, the article explores the main ways in which manipulative influence was evident in company-smallholders negotiations, and what effects these processes had on farmers' livelihood activities. It takes a rational-choice approach in which the material gains and losses that are perceived and anticipated by small-scale farmers as a result of their engagement in LSLAs form the focus of the analysis, although this does not necessarily exclude other potential social and cultural reasons for why farmers might hold on to or give up their land. This remains open to the possibility of farmers exercising agency and choice in their dealings with external actors (Long and Long, 1992) but also places these choices in the context of wider global economic relations that have historically served to marginalise small-scale farmers in the production process (McMichael, 2012).

In this way, the article advances three main reasons for why differentiating between coercion and manipulation in the implementation of LSLAs is a fruitful realm of study. The first is that a focus on coercion alone will likely only include a relatively small number of LSLA cases and exclude others that are producing significant effects on the livelihoods of small-scale farmers but fall short of outright compulsion. Manipulation is a more pervasive form of influence than coercion alone (Coons and Weber, 2014) and thus more central to farmers' experiences of engaging in LSLAs. It is necessary, therefore, to explore in greater depth than has been undertaken in the past what these experiences might be. 
Second, consideration of manipulation allows a more nuanced exploration of the power dynamics involved in the spaces between conventional coercion-resistance dichotomies during implementation of LSLAs. Manipulation thus helps provide a theoretical lens and vocabulary to more effectively cut through the rhetoric of voluntariness and choice that external land companies often utilise when dealing with small-scale farmers, thus exposing and explaining a wider range of decisions and outcomes than would otherwise be the case. To this end, the article's case study demonstrates the presence of three forms of manipulation - deception, pressure to acquiesce and playing upon people's emotions - which, while effective in meeting company objectives to plant trees, ended in widespread frustration amongst those farmers who had decided to lease land to the external investor.

Third, consideration of manipulation is helpful in highlighting the processes and effects of rural class differentiation. The case study examined in this article illustrates how the external investor took different approaches to different groups of farmers depending on the amount of land that they owned: better off farmers in ownership of more hectares were encouraged to lease their land in exchange for agricultural inputs whereas poorer small-scale farmers were offered the opportunity to sell their labour only.

The remainder of this article is divided into two parts. In the next part, the article expands upon what the expulsion-resistance narrative is, before introducing the concept of manipulation. Here, following the approach taken by Coons and Weber (2014), the term manipulation is presented in its descriptive sense, as a way of better understanding the means through which LSLAs are implemented and what the outcomes for small-scale farmers are, rather than necessarily as a method to denote actions that are deemed to be morally problematic. In other words, the primary intention is to comprehend a social process rather than to pass judgement on the ethical status of any particular organisation or individuals. In the second part, the case study from Mozambique is introduced and the empirical findings presented: these explore how the external investor attempted to incorporate small-scale farmers into its plantation project and illuminate the ways in which manipulative influence was exerted over landholders as part of this process. A key purpose here is to present the views and perceptions of small-scale farmers themselves so that their voices can be brought into ongoing debates surrounding the effects of LSLA projects. 


\section{LSLAs: from expulsion-resistance to inclusion/exclusion}

Although varying in its processes and effects, the expulsion-resistance narrative can be explained in terms of two main components. The first component concerns where companies choose to target their investments, and the discourses and practices that surround these choices. Proponents of LSLAs have often claimed that there are large areas of land in sub-Saharan Africa and elsewhere that are idle, unused or marginal in nature, relatively unpopulated, and thus ready for commercial exploitation by external investors (Nalepa and Bauer, 2012). For example, a widely-cited study produced by Cai et al. (2011) claimed that there was a total of 66 to 314 million hectares of "abandoned and degraded cropland" (p.334) potentially available for biofuel crop production in Africa alone.

Statistics such as these have helped set the conditions necessary for making land a suitable target for financial investment in the first place, part of what Li calls "the global land assemblage" (2014). However, as the pace and scale of investments have grown, claims that most LSLAs are indeed being targeted towards unused or idle land have increasingly been questioned. For example, Messerli et al. (2014), using a sample of 139 land deals from around the world, showed that approximately one third of these had been aimed at "densely populated and easily accessible areas", an observation which "substantiates case study-based criticism that the assumption about land deals targeting mostly idle or unused land is fundamentally flawed" (p.457). According to Exner et al. (2015), the language concerning unused and marginal land is rather a part of a set of state-bureaucratic or capitalist-economic narratives which aim to exclude "user-groups deemed irrelevant for national development" and "what is not profitable" respectively (p.652).

The second component of the expulsion-resistance narrative concerns what happens when LSLAs take place in fertile areas that are easily accessible and densely populated. Although the outcomes of LSLAs for the different stakeholders involved inevitably vary on a case-by-case basis, the one that has raised most concern is the phenomenon of dispossession through accumulation: a process whereby capitalist expansion results in the centralisation of wealth and power in the hands of a small number of individuals by dispossessing the public of their resources (Harvey, 2004). In this way, small-scale farmers can be coerced or forced off their lands to make way for large-scale plantations, a form of ex situ displacement (Feldman et al., 2003). For example, Feldman and Geisler (2012) have documented how, in Bangladesh, land grabs have commonly taken place in the form of physical appropriations. Faced by these expulsion processes, many small-scale farmers will attempt to prevent the LSLA projects from going ahead, either through open protest, as has occurred, for 
example, in response to Special Economic Zones in India (Levien, 2012), or via more subtle expressions of resistance, such as those documented in Scott's (1985) well-known work, Weapons of the Weak.

The notion of expulsion-resistance is important because it exposes the deeply unjust nature of global land-grabbing and shows how local communities might attempt to fight back. In recent years, these ideas have been explored in a wide range of empirical studies. As a result, understanding of how LSLAs proceed and their effects have been extended in three main ways. First, there is growing understanding that, although international corporations play a central role in LSLAs, there is a much wider range of actors operating in the land investment sphere than has conventionally been assumed. Most significant of these is the state itself, which, according to Wolford et al (2013), has often been portrayed as a victim of international LSLA projects when, in fact, its role is normally far more complex than this, with many governments acting as "active, calculating partners" (p. 192) in bringing land deals about and, in the process, evoking different kinds of powers within the state, such as the military, the police and the courts, sometimes acting in collusion with the external investor and other times taking a more oppositional stance. In addition, there often exists a set of non-state actors - so-called middlemen (Sud, 2014) or development brokers (Bierschenk et al., 2002) - who play an important role in shaping and facilitating land deals on the ground. Consideration of this wider set of actors, in addition to the actions of external corporates alone, is important if the full picture of LSLA drivers and effects is to be gained.

Second, it has been increasingly documented that, rather than simply rejecting LSLAs outright, the motives and interests of small-scale farmers can be highly varied, which results in smallholder reactions 'from below' being complex and differentiated (Borras and Franco, 2013). In particular, as Li (2011) argues, rather than seeing external investments as simply threats to their ways of life, some farmers might view them as offering new opportunities, particularly in rural areas that have long been neglected by government services. In this way, struggles by farmers for better terms of incorporation into large-scale land deals can be just as significant as struggles against them (Hall et al., 2015). These ideas have been explored empirically by McCarthy (2010), who demonstrated a wide range of livelihood outcomes amongst small-scale farmers following the expansion of an oil palm plantation in Sumatra, Indonesia, depending upon the terms under which smallholders were incorporated into the oil palm economy. 
Third, researchers have begun to explore the different ways in which external investors attempt to legitimise their LSLA projects in the face of potential bottom-up resistance. One common approach is to couch land acquisitions in the language of voluntariness whereby small-scale farmers and external companies are engaged in seemingly fair and transparent mechanisms of land exchange via the market. Such mechanisms might work for those farmers who are better educated and relatively well informed about the true value of their land. However, is it also the case that market-based mechanisms might be used to obfuscate a range of questionable practices, including coercion. This idea is explored in depth by Schmidt-Soltau and Brockington (2007) who showed how, in the case of conservation-linked resettlement projects, there is a risk that the language of voluntariness adopted by external investors might be used as cover under which to "freeride on the poorest and most marginalised segment of the global community" (p.2196).

There is little doubt that the idea of the market holds strong ideological power through which land deals can progress. Nevertheless, there is also recognition that, due to the highly political nature of many LSLAs, "the veiling capacity of the market's invisible hand" (Wolford et al., 2013;196) might be insufficient and so "an extra burden of ideological legitimation" can be required "as the state must explicitly justify to the dispossessed and to the public at large why it is expropriating property from one group for the benefit of another" (Levien, 2013;383). In this way, according to Kröger (2014), forest plantation expansion has occurred around the world via,

"The creation of pro-[plantation] territorial, social and symbolic spaces. Discourses are used to create the symbolic spaces for [plantations], to turn them into a tool for land control that is hidden by their presentation as non-political, solely positive-impact tools of development. The positive aesthetic valuations of [plantations], if rooted amongst decision-makers and society, accrue honour, symbolic value, to the social actors expanding them" (pp.246-247).

These insights have helped move forward the debate on LSLAs in important ways. Less critical attention, however, has been paid to the underlying notion of coercion itself that is often evident in the exclusion-resistance scenario but which might be less applicable to the more nuanced LSLA scenarios outlined above. While there are a number of different ways in which the ideas of coercion and influence might be unpacked (e.g. see Haugaard, 2009), it is suggested here that a concern with the incorporation of multiple actors, including small-scale farmers themselves, into land deals and the obfuscation processes that can accompany these processes, points us towards the concept and practice of manipulation. This is the main focus of the next section. 


\section{Manipulation and LSLAs}

Manipulation is a wide-ranging concept that that can be applied to both objects and people (Barnhill, 2014). In the terms of the former, manipulation expresses the operation of something in a skilful manner, such as the way in which a musician manipulates a violin or a scientist manipulates a chemical. In the case of LSLAs, the goal of the external investor is to directly manipulate the land that has been acquired through the use of machinery, labour or chemicals in order to generate profit (Fairbairn, 2014). In addition, there is a large number of other things that must be successfully and skilfully managed in order to turn land into a lucrative commodity, including computers and satellites which demarcate borders, and deeds and fences which create boundaries to exclude others (Li, 2014). Significantly, plantation owners are often in an advantageous position when it comes to the skilful manipulation of these physical elements compared to small-scale farmers. This can result in loss of small farms in favour of larger landholdings due to ongoing rural processes such as land fragmentation and degradation (Petrescu-Maga et al., 2017).

The second way in which manipulation is understood, that of people, constitutes the main focus of this article. Wood (2014), who provides a close examination of the subject, states that manipulation is best appreciated when juxtaposed alongside the better-known notion of coercion, the latter being conceptualised in terms of the existence or otherwise of acceptable alternatives. Thus, according to Wood (2014), "I am coerced to do something when I either do not choose to do it or if, when I choose to do it, I do it because I have no acceptable alternative" (p.21). Under the expulsionresistance narrative then, farmers who give up lands to the external investor will either do so against their will or do so because there is no other feasible choice that is offered to them. According to Dell'Angelo et al. (2017), outcomes such as these are often characterised by the presence of "explicit power imbalances and absence of safeguards for more vulnerable actors" during the land deals process (p.4). However, far less attention has been paid to manipulation of people, which is a subtler and arguably more pervasive type of influence. Thus, building on the definition of coercion provided above, Wood (2014) states that "manipulation refers to a way of interfering with or usurping someone's free agency that does not limit or destroy free choice (like coercion does) but, rather, influences it in certain ways that promote the outcome sought by the manipulator" (p.31). This includes rendering an option less attractive but does not include removing it or rendering it unacceptable. 
According to Baron (2003), there are three basic ways in which people's options, or their perceptions of them, can be affected by manipulation. The first is deception. This can involve out-and-out lying, such as making false promises, but might also include subtler attempts to mislead people in ways that do not actually misrepresent anything, including encouraging the development of wishful thinking, false assumptions or self-deception. Although manipulation by deception is often associated with a deliberate aim to misrepresent or mislead by the manipulator, Barnhill (2014) states that is not always the case. This is because of the difficulties involved in trying to establish the precise intentions of the influencer in the first place, and the tendency to presume that the manipulator "shares our rational ideals, that he is aware of his effect on [the manipulated], and that he is acting intentionally" (p.68) when this actually might not be the case.

The second is pressure to acquiesce, and can involve bullying, the attrition of another's resistance, and securing someone's agreement just to avoid further humiliation or uneasiness. In addition, there might be subtler techniques at work such as hurrying the subject along, pushing someone 'down a slippery slope', or using the factor of surprise against them. According to Wood (2014), threats should also be considered to be manipulative when the harm that they threaten falls short of being coercive.

Thirdly, manipulation can involve playing upon emotions, emotional needs, or weaknesses of character, a process sometimes referred to as psychological manipulation in the sense that it "induces changes in mental processes of the manipulated other than those involved in enhancing their understanding" (Barnhill, 2014;32). In addition to exploiting people's weaknesses, this form of manipulation can also play upon the apparently normal tendency to defer to those in authority and reluctance to incur the disapproval of others. Neither is this form of manipulation always emotional as it is also possible to manipulate people by overloading them with information, such as by 'blinding them with science' (Goodwin, 1980).

Given the different forms of manipulation outlined above, it might be expected that manipulation plays an important role in how LSLAs are implemented on the ground. However, there is very little empirical material that explicitly deals with the subject in the context of 'land grabbing'. Perhaps the closest example in the literature is the idea of illusive inclusion which, according to Joseph (2012), occurs in social settings in which "inclusion is ensured but the outcome is not different from that of being excluded" (p.6). An instance of illusive inclusion is provided by Mamonova (2015) who shows how, in the Ukraine, a land titling programme instigated in 2001, whilst meeting the emotional 
expectations of elderly small-scale landholders, did not lead to substantial material benefits being passed on to them. In addition to this case, then, what other examples might there be of small-scale farmers being incorporated into LSLA projects on a manipulative basis but in a manner that falls short of coercion? The aim of the remainder of this paper is to address this question through consideration of the case study from central Mozambique.

\section{Case study and methods}

Mozambique is one of the poorest countries in the world, currently ranked at 181 out of 188 nations in the UNDP's 2016 Human Development Index (UNDP, 2016). The country has undergone periods of strong national-level economic growth in the past ten years but much of this has failed to translate into development in rural areas, which have mostly remained economically stagnant (Aab $\varnothing$ and Kring, 2012). Around $75 \%$ of the population is primarily dependent on small-scale, rain-fed agriculture for an income, and the vast majority of farmers do not use fertiliser nor pesticide, and do not have access to credit. Average farm size is around 1.7 hectares but there can be considerable variation between households (Baez and Olinto, 2016). The poorest families tend to have the smallest and least favourably positioned plots of land, and the smallest number of livestock. In contrast, better off farmers will normally possess larger farms (up to ten hectares or more) and much higher numbers of livestock, and might also have access to mechanised inputs or farm labour. Food insecurity is a major problem across the country, with the average farming household struggling to produce sufficient food to feed the family during the entire year (Cunguara and Hanlon, 2012).

Mozambique has about 80 million hectares of land in total, although much of this is used for concessions, small-scale farming or ecological areas. Officially, all land is owned by the state, with the main tenets of land ownership being established in the Land Law of 1997. Under the Land Law, the only legally recognised form of land tenure right is the DUAT (dereito de uso e aproveitamento da terra). There are three ways in which an individual might secure a DUAT:

- Customary, or traditional occupation, through inheritance. This is the major way in which land is owned.

- 'Good faith' occupation, whereby someone has utilised land for at least ten years without objection.

- Awarded on a concessionary basis by the state, following an application submitted by an individual or corporation for a leasehold of up to 50 years. The application must be based on an approved investment proposal, payment of annual rents, and a community consultation. The 
consultation process, which is described under the Diploma Ministerial no. 158/2011, should occur over two main phases and involve a range of actors, including the district administrator or their representative, a representative of the land registry services, the external land investor and the landholders themselves. The outcomes of the process should also be disclosed to the wider community "in order to ensure [their] effective participation...in the management of land and natural resources" ${ }^{\prime 1}$.

As of 2017, the online Land Matrix database for Mozambique shows that a total of 85 transnational deals have been concluded orally or via a signed contract via the DUAT system, mostly for agriculture or forestry. The size of these deals vary greatly, from hundreds to tens of thousands of hectares. It is also possible for small-scale farmers holding land in the customary manner to secure a DUAT by formally registering their land with the state. However, this is rarely done in practice, with DUAT ownership amongst this group standing at around only two to three percent (Baez and Olinto, 2016).

Mozambique's Land Law is widely recognised as, on paper at least, one of the most progressive in sub-Saharan Africa and a genuine attempt to balance the interests of small-scale farmers with those of external investors. However, there are major challenges relating to its implementation, particularly with regard to the consultation process, which is often carried out poorly, if at all, with little information being provided to communities which are being asked to lease out land ${ }^{2}$. As a result, the land debate in Mozambique to date has been characterised by campaign groups mostly in terms of the expulsion-resistance narrative outlined above (e.g. see Beekman and Veldwisch, 2012). Probably the best known example of this is the highly publicised and controversial sugarcane project, ProCana. This consisted of 30,000 hectares of land that was contracted out by the Mozambican government in 2007 in Massingir District, Gaza Province (Borras et al., 2011). However, following widespread protests by small-scale farmers fearing the loss of their lands and civil society organisations, ProCana was cancelled in 2009 by the Mozambican government, citing noncompliance with contractual clauses by the external investor.

Nationally, there is a long history of eucalyptus and pine forestry concessions that dates back to the colonial era and, since independence, the Mozambican government has tried to attract foreign investment in plantations with mixed levels of success. In recent years, more than one million

\footnotetext{
${ }^{1}$ For a comprehensive discussion of Mozambique's Land Law in relation to LSLAs, see Hanlon (2011).

2 Discussion with NGO manager, Chimoio, Mozambique, 12 August 2015.
} 
hectares of land in central and northern Mozambique have been claimed by investors for forestry monocultures (Hanlon, 2011). The particular project being examined in this article concerns a company that was granted a 50-year land use license for an area of 173 thousand hectares in Zambézia Province and 183 thousand hectares in Manica Province for creation of eucalyptus plantations, the largest in the country ever undertaken. The project has received international donor approval, including a loan from the International Finance Corporation (IFC) of US\$ 2.3 million, thus securing the IFC a twenty percent stake in the company.

The company website states that the intervention offers "vast social and economic benefits for Manica and Zambézia provinces, and for the country as a whole". It claims to be producing a total of 7500 jobs via its investment and intends to create a factory to come into operation in the centre of the country by the end of 2023 to produce 1.3 million tonnes of pulp per year. There is also a community development component to the project, estimated at \$US 40 million, which is expected to reach 130,000 people in Manica and Zambézia. In spite of these intended benefits, however, much of the response from civil society to the company has been negative, with the potential impacts of the project on farmers' livelihoods and capacity to produce food being highlighted in particular.

Manica Province, which forms the focus of this work, has an area of $62,272 \mathrm{~km}^{2}$. The company's concession in Manica is located in five districts, Bárue, Gondola, Manica, Mossurize and Sussundenga, and the fieldwork for this research took place in Gondola and Sussundenga. These two districts were purposively selected in order to represent different farm types under the same LSLA project. In Gondola, there are 598 families located inside the company concession, organised into five villages. Farm sizes in Gondola are typically small, being one to two hectares each, and many families in the area are relative newcomers, having moved to the district following the cessation of the county's civil war in the early 1990s. Many farmers practice shifting agriculture, working in the same plot for three years before moving on to the next, and formal registration of land under the DUAT system is very rare. In addition to farming, families use their lands for a range of other purposes, including animal grazing, charcoal production, grass collection for house construction, and honey production.

In Sussundenga, the company's concession extends across three districts and 36 farming households have been directly affected by plantation activities. Farms in the districts are generally larger establishments in comparison to Gondola, typically being 5-20 hectares each. This is due to the fact 
that, unlike in Gondola, Sussundenga has long been a focus of large-scale farming operations extending back to the colonial era. Many Mozambican farmers resident in the district were involved in colonial farming operations as agricultural managers and therefore inherited land when the Portuguese left in 1975. Most of the larger, better-off farmers in Sussundenga possess DUATs and have access to hired labour, but they can also lack access to inputs such as mechanisation, fertilisers and pesticides.

Fieldwork in Manica Province took place over two periods of three weeks each in August 2015 and April 2016. A total of 15 semi-structured interviews with key informants were carried out in the provincial capital, Chimoio, during which a range of issues concerning rural development, LSLAs, forestry plantations and small-scale farming were discussed. Key informants were purposively sampled using a snowballing technique and constituted eight representatives of rural development NGOs, three academics, two stakeholders from Chimoio's business community, and two company employees. In addition, 20 group-based interviews of two or three people at a time were carried out with farmers who had leased land to the company (14 in Gondola and six in Sussundenga) to discuss their livelihoods and interactions with the company. Three interviews were also conducted with small-scale farmers who had, for various reasons, refrained from leasing land to the company. Roughly equal groups of men and women, leaders and non-leaders, and old and young were selected, with individuals being sampled in consultation with local stakeholders in order to ensure that a range of social groups were represented. Secondary data were also collected including reports produced by the company, provincial and district government, and NGOs based in the region.

All research was carried out subject to approval by the standard ethical research procedures established at the author's home institute, and in Mozambique established procedures were followed at provincial, district and village levels in order to gain access to respondents. Interviews were conducted in the local language, Sena, for which an experienced translator was hired and trained in the objectives of the research. Discussions were recorded during meetings and then transcribed into Word immediately afterwards. The researcher also kept a field dairy in which observations, thoughts, feelings and ideas were recorded as the research progressed. In addition, data collection benefitted from informal discussions and observations that occurred through visits to affected communities, with insights gained from these also being recorded in the field diary for later recall. 


\section{LSLAs and manipulation: voices from the grassroots}

This section draws on the empirical data to explore the evolution and effects of the company's project in central Mozambique. Section 5.1 places the development of the project in light of the debates outlined in section 2 to explain how and why the company attempted to negotiate access to land on a plot-by-plot basis. Section 5.2 examines farmers' claims that the benefits of the LSLA had been misrepresented, or that they were misled during their negotiations with the company during their incorporation into the project. Section 5.3 shows how people's attitudes towards the company's presence and actions were influenced.

\subsection{Negotiations on a one-to-one basis}

The company's first step in Mozambique was to obtain approval for its project in the national capital, Maputo, from the Mozambican government via a Council of Ministers Resolution of 19 December 2011. From Maputo, the company then moved to the Provincial cadastral office in Manica to finalise the boundaries of its new concession. At the time, according to cadastral records, a total of 695,565 hectares of land was showing as free or empty in the Province, from which the company was allocated 183,000 hectares. However, when the company's field managers travelled to the region that had been allotted to them for inspection, they found very large numbers of famers settled within the newly-granted concession. In fact, the company's environmental and social baseline report stated at the time that the total number of inhabitants came to 66,831 people. Most of these were smallholders but there were also farmers with larger plots of land, including immigrants from Zimbabwe and South Africa. On discovering these farmers, the company's management returned to government representatives to explain the situation, but were informed that the concession was no longer the government's responsibility and that the investor would have to deal with the farmers.

This case provides an example of how an international company, rather than securing land that is somehow marginal in nature, was in fact allocated land that is fertile and populated. It also demonstrates the central role that government played in this outcome, although the degree to which the company was duped in a deliberate fashion is open to debate. On the one hand, it is likely that the Provincial cadastral services would not have been aware of most existing agricultural activity taking place inside the concession. This is due to the fact that the majority of small-scale farmers are unwilling or unable to register their land, or unaware of the need to do so. On the other hand, it is possible that cadastral services were encouraged by national-level land-owning elites to 
downplay the level of farmer occupation of the designated area in order to ensure that the deal with the company, from which they would personally benefit, was signed ${ }^{3}$.

The company's response to this situation was to adopt a land management system based on an "innovative mosaic approach" in which eucalyptus production would be developed over a period of 12 years alongside "improvements to community farming systems, ecosystem services, and preservation of high conservation value areas so important to local communities" ${ }^{4}$. The mosaic system, then, allowed the company to avoid the problems associated with the expulsion of smallscale farmers from their lands, presenting instead a vision of a shared space and shared benefits in which families could engage voluntarily with the company to negotiate land use on a one-to-one basis. In this way, the company committed to only planting on 70 percent of the land that it had been allocated, signing "land sharing agreements with communities or families wanting to join the project" and "ensuring they are left with enough land for their needs, and working with them to increase their agricultural yields and income". The remaining 30 percent of land would act as designated "community spaces" which would allow the development of a "sustainable forest".

These aims required a high level of brokerage with local communities to achieve. A number of negotiators or middlemen, often former officials from district government, were therefore hired by the company to liaise directly with community leaders and farmers. This approach was intended to follow the community consultation process as required under the Land Law, although the extent to which it was fully implemented varied from district to district, with community members in some areas reporting that they had remained unaware that any land deals had been agreed in the first place until the land clearance activities of plantation development had actually begun. Overall, the approach taken by company representatives to negotiation was primarily determined by the particular socioeconomic characteristics of the farming communities that they encountered, with an assessment being made on a case-by-case basis concerning what should be offered in exchange for land. Thus:

- Better off farmers with larger areas of land, as in Sussundenga, were commonly offered a deal whereby the company would commit to cultivating a certain proportion of the land (normally ten percent) provided to it, returning all profits generated from that cultivation to the farmer for a period of three years. Much of the land that was leased out in this manner was not under

\footnotetext{
${ }^{3}$ Informal discussion with NGO manager, Chimoio, $5^{\text {th }}$ May 2016.

${ }^{4}$ Source: IFC website: www.ifc.org.
} 
cultivation at the time as it was, due to resources constraints, beyond the abilities of individual farming households to cultivate.

- Poorer farmers with smaller areas of land, as in Gondola, were commonly offered employment as plantation workers in exchange for land at a rate of one job for every four hectares leased to the company. As part of this employment package, farmers would receive protective clothing, tools, free healthcare and breakfast. Much of the land that was provided by small-scale farmers in this manner was used by them on a regular basis for crop cultivation and was considered to be important to their day-to-day livelihoods activities.

As a result, the majority of farmers approached by the company provided a proportion of their land to the company. Once a deal was struck, agreements were formalised with individual farmers via an Acordo para uso e aproveitamento da terra (Agreement for use and improvement of land) which contained a description of the rights and responsibilities of both company and farmer, and was signed by both parties. This mechanism was intended to ensure that agreements were being arrived at in an open and transparent manner.

Due to the need to negotiate individually with each farmer, the tree planting process progressed relatively slowly, with the company reporting in 2016 that it had planted 7.1 million trees on 5,300 hectares of land, bringing its Mozambique planting to 10,000 hectares in Zambézia and 1,700 hectares in Manica. Nevertheless, by taking this approach, some key informants believed that the project in Manica had occurred on an entirely voluntary basis, and that the company had done the right thing by avoiding the problems of the past associated with farmer expulsions and damaging conflicts with local communities. As one district leader commented, "Each farmer has been given a choice: they can lease land to [the company] or choose not to. Some can even try to grow eucalyptus themselves if they want, or are free to leave the area... This is the best approach that [the company] could have taken and we are grateful to them for doing it in this way" (KII 4; 10/10/15).

It is certainly the case that very few, if any, smallholders experienced coercive ex situ displacement as a result of the company's project. Nevertheless, by 2015, levels of dissatisfaction with the company amongst farmers had grown considerably, with many reporting a lack of materialisation of benefits and difficulties maintaining their livelihoods in situ. This outcome is perhaps surprising given the lengths that the company went to in attempting to reach agreements with each farmer on an individual basis. However, such an outcome is better understood when placed in the context of the

\footnotetext{
${ }^{5}$ Key Informant Interview (KII)
} 
three main ways in which people's options can be manipulated: deception, pressure to acquiesce, and playing upon people's emotions. In the two sections that follows, each is considered in turn.

\subsection{Deceptive influence}

The vast majority of farmers interviewed believed that the investor's negotiators had misrepresented the benefits that they would receive in exchange for leasing land, or that the company had failed to keep the promises that it had made to them. As described above, the company's presence in Sussundenga provided many better-off farmers with an opportunity to increase the productivity of their land. However, following one season of agricultural production, the company suddenly scaled down its operations, claiming to have realised that producing crops for farmers in the manner that it had offered did not make commercial sense, and that such a system was encouraging idleness amongst landowners. For this reason, the company's level of activity fell from ten percent in the first year to seven percent in the second year. Then, in the third year, the company stopped work altogether, choosing to provide cash compensation and seeds instead. The level of cash compensation was meant to be based on the productivity and price of the crop. Nevertheless, farmers in Sussundenga complained that the compensation was too little and that the seeds that they had been given were of poor quality.

Whereas better off farmers negotiated with the company in terms of capital inputs into their landholdings, poorer farmers were overwhelmingly concerned with gaining employment from the investor. Indeed, it is well understood in Mozambique that what many rural communities desire most are jobs, and these are often preferred to working on the land, which can be seen as hard work and unprofitable. Thus, following the company's arrival in Gondola, expectations surrounding employment became very high, and it was believed that the jobs provided by the company would be plentiful and of good quality. As one farmer stated, "We thought we would have guaranteed employment until the age of 50, and that if we died before this time then our children could replace us. We thought we'd have employment until the end of the world" $\left(\mathrm{GBI}{ }^{6} 02 ; 12 / 08 / 15\right)$. It was even reported that a small number of individuals had recently moved into the district and purchased new land in an attempt to gain access to employment. Moreover, it was stated during interviews that company representatives had encouraged people to view the land investments in an optimistic manner, or had facilitated the development of wishful thinking. As one academic expert on Mozambican agriculture explained, "Sometimes people automatically think that because it is a very

\footnotetext{
${ }^{6}$ Group-based interview (GBI)
} 
big investment with a lot of land, then the company must be hiring a lot of people. This is the assumption that people make, and the company plays on this" (KII 14; 09/04/16).

In spite of farmers' initial hopefulness, as previous field-based studies have shown (for example, see Chinsinga et al., 2013; Romijn et al., 2014), labour opportunities provided by large-scale plantations are often short-term. This was also the case in Gondola where a large number of concerns was highlighted by respondents. The main ones are summarised in Table 1, alongside illustrative quotations.

Table 1: Main concerns amongst company employees in Gondola District accompanied by illustrative quotations

\begin{tabular}{|l|l|}
\hline Concern & Illustrative quotation \\
\hline $\begin{array}{l}\text { People treated } \\
\text { differently in an } \\
\text { arbitrary manner }\end{array}$ & $\begin{array}{l}\text { "The work is very variable. Some people get a fulltime job for a whole year } \\
\text { and then nothing whereas other people get low levels of part time work for } \\
\text { much longer. It's not clear why this is. We think that the work should be the } \\
\text { same for everybody." (GBI 07; 31/03/16) }\end{array}$ \\
\hline $\begin{array}{l}\text { No fixed days } \\
\text { ('zero hours' } \\
\text { contracts) }\end{array}$ & $\begin{array}{l}\text { "We are just called to work with no warning. But we don't get paid for the } \\
\text { days that we do not work, even if we are sick. Last month my nephew, who } \\
\text { was working for [the company] for three months, became ill and so could } \\
\text { not work for two weeks. But the company did not pay him and then found } \\
\text { someone else to do his job." (GBI 17; 12/04/16) }\end{array}$ \\
\hline $\begin{array}{l}\text { Declining quantity } \\
\text { of work }\end{array}$ & $\begin{array}{l}\text { "I had fulltime work for the first six months, for clearing [the land] and } \\
\text { planting. But now the work is decreasing as the company is using herbicides } \\
\text { instead of people to clear the weeds...Sometimes the company brings in } \\
\text { outside workers rather than employ local people." (GBI 10; 02/04/16) }\end{array}$ \\
\hline $\begin{array}{l}\text { Difficult work } \\
\text { conditions }\end{array}$ & $\begin{array}{l}\text { "The work is hard and the pay is low. The company promised to provide us } \\
\text { with protective clothing and breakfast in the morning but we never received } \\
\text { these things...The company said that it would provide free healthcare but } \\
\text { no one has been sent to the clinic since [the company] arrived." (GBI 11; } \\
\text { 03/04/16) }\end{array}$ \\
\hline Delays in payment & $\begin{array}{l}\text { "Sometimes there are delays in payment after we have completed the work. } \\
\text { We finish work but then we are told that the money is not yet available but } \\
\text { it is being organised...These [delays] are up to 45 days in some cases. } \\
\text { Others have worked but they have not been paid for all the days that they } \\
\text { have completed." (GBI 20; 16/04/16) }\end{array}$ \\
\hline $\begin{array}{l}\text { Lack of contract of } \\
\text { employment }\end{array}$ & $\begin{array}{l}\text { "The people were expecting a contract, but it did not arrive. A contract } \\
\text { company is... We would have turned [the company] down if we knew that a } \\
\text { contract would not arrive." (GBI 15; 07/04/16) }\end{array}$ \\
\hline
\end{tabular}

As a result, farmers in Gondola felt that a fair exchange with the company had not occurred. This sense of injustice was exacerbated by the fact that, unlike farmers in Sussundenga who were mostly able to continue their agricultural operations as before, the livelihoods of small-scale landholders were curtailed by reduced access to land. Before the arrival of the company, many farmers in 
Gondola had used the full extent of their plots for collection of natural resources, such as charcoal, firewood and grass, for shifting agriculture, and for animal grazing. However, after passing land over to the company, access to these resources was restricted as farmers were no longer allowed to utilise company land. An additional concern was that the time spent working on the company's plantation was time away from farmers' own fields and that their own crops could suffer as a result. This problem was worsened by the fact that irregular work and pay meant that farmers were unable to plan ahead to manage their own farms. For example, one respondent, who owned three hectares of land, two of which had been leased to the company, stated, "We don't get fixed days so we cannot plan to manage our own farms. We might be able to hire someone [to work on our farms], but we can't plan from one day to the next" (GBI 19; 14/04/16).

\subsection{Manipulation of thoughts and feelings}

Section 5.2 considered a form of manipulation that aims to influence what farmers immediately decide or do (i.e. to lease or to not lease land to the company). However, as stated by Barnhill (2014), manipulation can also be aimed at changing how someone thinks or feels, without attempting to affect their immediate behaviour. This latter form of influence was evident in the way that the company and government representatives tried to shape how famers perceived the company through exerting pressure to acquiesce to a higher authority and by playing upon people's desires for local development.

In terms of the former, farming communities in both Sussundenga and Gondola reported being informed that the investments that the company was making were "for the President [of Mozambique]" (GBI 19; 14/04/16) and that the President personally wanted the company to be in the area. This quotation reflects an approach towards the establishment of LSLAs in Mozambique previously reported by Hanlon (2011), whereby project proponents "attempt to give the impression that they are powerful, or are sent by powerful people, or have been given decision making power by higher authority" or "put pressure on district administrators and local chiefs to rush through consultations and approvals - often saying the governor or president demands they agree" (p.46).

In addition, pressure to enter negotiations with the company was placed on some farmers by officials from provincial- and district-level cadastral services who reminded landholders that, under the country's land laws, farmers were obliged to keep all of their land productive and that, if they failed to do so, then the government had the right to take 'underused' land from them. Although the relative unlikeliness of this threat being carried out made it fall short of actual coercion, reminding 
farmers of the country's Land Law in this manner was sufficient to alter farmers' perceptions of the options that were available to them. For example, João, a small-scale farmer who had leased half of his three hectares to the company stated, "We were reminded that all land in Mozambique belongs to the government and the government has the power to take it back if it's not being used optimally. So we thought that it might be safer if some of it went to [the company]" (GBI 07; 31/03/16).

In terms of people's emotions, company negotiators played upon leaders' desires for district-based economic development and jobs in an attempt increase the acceptability of the company's presence and actions. Thus, community leaders in Gondola stated that, during initial meetings with company representatives, "[the company] came to us and said that it is going to be a huge benefit to the country and that we have the chance to play our part in helping to achieve this" (GBI 08; 31/03/16). This claim had greatly enhanced the acceptability of the company in the eyes of community leaders, although it was never specified how national-level benefits were going to accrue to improve people's livelihoods at sub-district levels. Moreover, it was reported during interviews that it was frequently claimed by the company that investments in physical and social infrastructure, such as bridges, roads, schools and hospitals, would boost local economic growth, thereby facilitating further investment in the area. For example, in one community in Doroi, one of the company's first actions was to organise a large meeting in a nearby primary school during which the company stated that its project would lead to the construction of a local road and bridge. However, community leaders also explained that this investment was not subsequently realised and no account for why this was the case had been provided to them.

While many communities were hopeful that the benefits that company representatives had discussed with them would eventually materialise, most key informants had low expectations that they would ever arrive. For example, a prominent businessman based in Chimoio claimed that, "[the company] have set aside four to five million US dollars for social development but they will only spend a fraction of this. They are meant to be building hospitals and schools but they will still be planning to do this in ten years' time" (KII 15; 16/04/16). There was a general view, then, that whilst the company's project had the potential to deliver much-needed infrastructure upgrades to areas where the LSLA was operational, the claim that plantations would bring long-term benefits to local economies was a calculated measure designed to bring about a positive view of the company and its operations. This, it was argued, was part of an attempt to encourage people to lease out land rather than any serious effort to stimulate local development. 


\section{Conclusion}

In Mozambique, the coercive expulsion of farmers from their lands is unlikely, given investor reluctance to stir up potentially damaging conflicts with farming communities. Rather, it is far more likely that investors planning LSLAs will talk up the benefits of their projects in terms of jobs and local infrastructure whilst seeking to engage in a process of negotiation with those small-scale farmers whose land they seek. This is particularly the case when large companies attempt to implement sustainable mosaic-based approaches to land management based on principles of shared use of the landscape. As one manager of a land governance NGO stated, "The aim is not to avoid or cut external investment but to make it fair - to make it win-win. Mozambique needs investment in its rural areas. But can it be fair?" (KII 15; 16/04/16)

In this article, the evidence demonstrates that there is some to go before the types of negotiation processes examined can be referred to as resembling fair. Small-scale farmers were portrayed as being provided with a set of options concerning the quantity of land that they wished to pass on to the company, and being free to choose between those options based on each families' individual circumstances and priorities at the time. However, through the process of manipulation, company representatives in Sussundenga and Gondola districts were able to influence farmers' decisions to lease land, or to change how people viewed the external investor, by altering landowners' perceptions of the options that were available to them. In many cases, farmers subsequently regretted their decisions to lease their land out but were unable to rectify their actions once work to establish the plantation had begun.

Overall, these findings demonstrate the importance of manipulation, the form of influence that lies between coercion, the traditional focus of critical LSLA scholarship, and encouragement or persuasion based on voluntary decision-making by smallholders, which governments and external investors would like to be seen as facilitating. According to Milgroom (2015), there often exists in LSLA projects a significant gap between policy intention, such as the protection of land tenure, and policy in practice, the so-called "interface of politics 'in the air' and 'politics on the ground"' (p.585). The concept of manipulation, then, can be one way of trying to understand the shape and form of this interface during the implementation of LSLA projects, as company representatives attempt to push planned land investments through towards realisation. By taking the idea of manipulation into account in this manner, it becomes possible to reveal more subtle, nuanced, but nevertheless consequential, influences over smallholders that might otherwise go unrecognised by researchers, policymakers and commentators. Moreover, these influences might be targeted at different social 
groups in varying ways, thus reflecting indigenous processes of rural class differentiation, as illustrated by the manner in which company negotiators took different approaches to farmers in Sussundenga and Gondola. In many cases, better off farmers in possession of larger numbers of hectares were able to lease 'excess' land to the company whereas poorer farmers with only a few hectares attempted to substitute land that was central to their livelihood activities for jobs which sometimes did not materialise.

The case study presented in this article highlights new policy challenges concerning the best way to deal with the potential problem of manipulation in land grabs. In recent years, international policymaking on LSLAs, such as the 2010 Principles for Responsible Agricultural Investment developed by, amongst others, the FAO and World Bank, has tried to establish the importance of transparency, and good quality consultation and participation, as key ingredients to successful land deals based on win-win outcomes for all stakeholders involved, including relatively powerless landholders themselves. These principles were reflected in the case study presented in this article by the development of written contracts clearly setting out tenure rights and responsibilities regarding land. However, these documents said nothing about what benefits farmers were entitled to, these being subject to agreements arrived at on a mostly informal basis between company representatives and landowners. As a result, there was scope for manipulation of farmers' expectations of those benefits, a situation which could have been avoided if all entitlements and benefits had been put into writing and an effective mechanism for dispute resolution established at the outset.

All of this, of course, is not to claim that the company set out to deliberately deceive the landowners with which it was negotiating; this is because, as noted above, establishing the degree of intentionality in the case of the influencer is often difficult to determine. Nevertheless, it was certainly the case that the small-scale farmers interviewed in Sussundenga and Gondola believed that the benefits of leasing out land to the company had been misrepresented to them, or at least over-stated by the negotiators acting on the investor's behalf. Interestingly, the case study also points to a certain degree of deception of the company itself by government representatives at the national level, who appeared to dupe the investor into believing that the land that they were being allocated for plantation development was uninhabited. This process reflects the active and calculating role that developing country governments can take vis-a-vis LSLA processes occurring within their national boundaries, a process which in Mozambique led to the company attempting to establish its mosaic approach to tree-planting. However, it now appears that the challenges presented by the situation in Manica have been too great for the company, with the decision by its 
management in 2016 to scale back its operations in the province, concentrating 70 to 80 percent of its activities in Zambézia instead, where there are fewer farmers located. Whilst this news might be welcomed by some who have campaigned against LSLAs in general, in the context of stagnant economic growth and high levels of poverty in the centre of the country, it would likely be a mistake to dismiss the potential of large-scale plantations to deliver development altogether. Making transparent and addressing the problems presented by the phenomenon of manipulation would surely be a step in the right direction towards delivering rural investment projects in a manner that could be considered as something akin to fair.

\section{References}

Aabø, E., Kring, T., (2012) The Political Economy of Large-Scale Agricultural Land Acquisitions: Implications for Food Security and Livelihoods/Employment Creation in Rural Mozambique. United Nations Development Programme, Maputo.

Baez, J.E., Olinto, P., (2016) Accelerating Poverty Reduction in Mozambique: Challenges and Opportunities. World Bank Group, Washington DC.

Barnhill, A., (2014) What is manipulation?, in: Coons, C., Weber, M. (Eds.), Manipulation. Oxford University Press, New York.

Baron, M. (2003) Manipulativeness Proceedings and Addresses of the American Philosophical Association 77.

Beekman, W., Veldwisch, G.J. (2012) The evolution of the land struggle for smallholder irrigated rice production in Nante, Mozambique. Physics of the Chemistry and Earth 50-52, 179-184.

Bierschenk, T., Chauveau, J.P., Olivier de Sardan, J.P., (2002) Local development brokers in Africa: The rise of a new social category, Working Papers No. 13. Institut für Ethnologie und Afrikastudien, Johannes Gutenberg-Universität.

Borras, S., Franco, J.C. (2012) Gobal land grabbing and trajectories of agrarian change: a preliminary analysis Journal of Agrarian Change 12, 34-59.

Borras, S., Franco, J.C. (2013) Global land grabbing and political reaction 'from below'. Third World Quarterly 34, 1723-1747.

Borras, S.M., Fig, D., Suárez, S.M. (2011) The politics of agrofuels and mega-land and water deals: insights from the proCana case, Mozambique. Review of African Political Economy 38, 215-234.

Cai, X., Zhang, X., Wang, D. (2011) Land availability for biofuel production. Environmental Science and Technology 45, 334-339.

Chinsinga, B., Chasukwa, M., Zuka, S.P. (2013) The political economy of land grabs in Malawi: investigating the contribution of Limphasa Sugar Corporation to rural development. Journal of Agricultural and Environmental Ethics 26, 1065-1084.

Coons, C., Weber, M. (2014) Manipulation. Oxford University Press, New York.

Cunguara, B., Hanlon, J. (2012) Whose wealth is it anyway? Mozambique's outstanding economic Growth withWorsening Rural Poverty. Development and Change 43, 623-647.

Dell'Angelo, J., D'Odorico, P., Rulli, M.C., Marchand, P. (2017) The tragedy of the grabbed commons: coercion and dispossession in the global land rush. World Development 92, 1-12.

Exner, A., Bartels, L.E., Windhaber, M., Fritz, S., See, L., Politti, E., Hochleithner, S. (2015) Constructing landscapes of value: Capital investment for the aquisition of marginal or unused land - The case of Tanzania. Land Use Policy 42, 652-663.

Fairbairn, M. (2014) 'Like gold with yield': evolving intersections between farmland and finance. Journal of Peasant Studies 41, 777-795. 
Feldman, S., Geisler, C. (2012) Land expropriation and displacement in Bangladesh. The Journal of Peasant Studies 39, 971-993.

Feldman, S., Geisler, C., Silberling, L. (2003) Moving targets: displacement, imporversihment and development. International Social Science Journal 175, 7-13.

Goodwin, R. (1980) Manipulatory Politics. Yale University Press, New Haven.

Hall, R., Edelman, M., Borras, S.M., Scoones, I., White, B., Wolford, W. (2015) Resistance, acquiescence or incorporation? An introduction to land grabbing and political reactions 'from below'. The Journal of Peasant Studies 42, 467-488.

Hanlon, J., (2011) Understanding land investment deals in Africa. The Oakland Institute California.

Harvey, D. (2004) The 'new' imperialism: accumulation by dispossession. Socialist Register 40, 63-87.

Haugaard, M., (2009) Power and hegemony, in: Clegg, S.R., Haugaard, M. (Eds.), The Sage Handbook of Power. Sage, London.

Joseph, K.J., (2012) In search of spaces of social inclusion in innovation systems: the case of plantation agriculture in India, International Conference on Development and Innovation in the Emerging Economies, Punjabi University, India.

Kröger, M. (2014) The political econonmy of global tree plantation expansion: a review. The Journal of Peasant Studies 41, 235-261.

Levien, M. (2012) The land question: speciale economic zones and the political economy of dispossession in India. The Journal of Peasant Studies 39, 933-969.

Levien, M. (2013) Regimes of dispossession: from steel towns to Special Economic Zones. Development and Change 44, 381-407.

Li, T.M. (2011) Centering labor in the land grab debate. The Journal of Peasant Studies 38, 281-298.

$\mathrm{Li}, \mathrm{T} . \mathrm{M}$. (2014) What is land? Assembling a resource for global investment. Transactions of the Institute of British Geographers 39, 589-602.

Long, N., Long, A. (1992) Battlefields of knowledge: the interlocking of theory and practice in social research and development. Routledge, London.

Mamonova, N. (2015) Resistance or adaptation? Ukrainian peasants' responses to large-scale land acquisitions The Journal of Peasant Studies 42, 607-634.

McCarthy, J. (2010) Processes of inclusion and adverse incorporation: oil palm and agrarian change in Sumatra, Indonesia The Journal of Peasant Studies 37, 821-850.

McMichael, P. (2012) The land grab and corporate food regime restructuring. The Journal of Peasant Studies 39, 681-701.

Messerli, P., Giger, M., Dwyer, M.B., Breu, T., Eckert, S. (2014) The geography of large-scale acquisitions: Analysing socio-ecological patterns of target contexts in the global South. Applied Geography 53, 449-459.

Milgroom, J. (2015) Policy processes of a land grab: at the interface of politics 'in the air' and politics 'on the ground' in Massingir, Mozambique. Journal of Peasant Studies 42, 585-606.

Nalepa, R.A., Bauer, D.M. (2012) Marginal lands: the role of remote sensing in constructing landscapes of value. The Journal of Peasant Studies 39, 403-422.

Petrescu-Maga, R.M., Petrescub, D.C., Petrescu-Magc, I.V. (2017) Whereto land fragmentation-land grabbing in Romania? The place ofnegotiation in reaching win-win community-based solutions. Land Use Policy 64, 174-185.

Romijn, H., Heijnen, S., Colthoff, J.R., de Jong, B., van Eijck, J. (2014) Economic and social sustainability performance of Jatropha projects: results from field surveys in Mozambioque, Tanzania and Mai. Sustainability 6, 6203-6235.

Schmidt-Soltau, K., Brockington, D. (2007) Protected areas and resettlement: what scope for voluntary relocation? World Development 35, 2182-2202.

Scott, J.C. (1985) Weapons of the Weak: Everyday Forms of Peasant Resistance Yale University, New Haven.

Sud, N. (2014) The men in the middle: a missing dimension in global land deals The Journal of Peasant Studies 41, 593-612. 
UNDP, (2016) World Development Report 2016: Human Devleopment for Everyone World Development Report. United Nations Development Programme, New York.

Wolford, W., Saturnino, M.B., Hall, R., White, B. (2013) Governing global land deals: the role of the state in the rush for land. Development and Change 44, 189-210.

Wood, A.W., (2014) Coercion, manipulaiton, exploitation, in: Conns, C., Weber, M. (Eds.), Manipulation. Oxford University Press, New York 